\title{
Optimistic View of Life Reflected In the Style of Paulo Coelho's THE ALCHEMIST (1988)
}

\author{
Danang Wiratnoko Suwasono, M. Thoyibi, Phil.Dewi Candraningrum \\ Universitas Muhammadiyah Surakarta \\ nokojkt@gmail.com
}

\begin{abstract}
This study aims at explaining the symbols used in the novel and describing the values of optimistic of life reflected in the symbols used in Coelho's The Alchemist. This research is classified as a descriptive qualitative method. The primary data source of this study is the novel The Alchemist by Paulo Coelho. The collecting data process is a notetaking technique. This study is also categorized as library research. Based on the findings and discussion, the researcher draws the conclusion such follows. First, there are six elements or values which characterize someone as the one who has an optimistic view of life and these ones are reflected as the symbols used in this novel. They are the values of hope, faith, power, struggle, positive-thinking, and respect. Second, that there are twelve symbols used in The Alchemist, those symbols are divided into three groups which consist of four symbols of characters, two symbols of events or concepts and six symbols of things. The result of the study shows that the twelve symbols in The Alchemist are how the author addresses Optimistic through a story of self-quest of the author. According to the whole finding, the symbols lead the readers to understand the message of Paulo Coelho that everybody can find their happiness in themselves.

Keywords: Concept of optimistic of life, Symbol, Self-quest.
\end{abstract}

\begin{abstract}
Abstrak
Penelitian ini bertujuan untuk menjelaskan simbol-simbol yang digunakan dalam novel dan menggambarkan nilai-nilai optimistis kehidupan yang tercermin dalam simbol-simbol yang digunakan dalam Coelho's The Alchemist. Penelitian ini diklasifikasikan sebagai metode deskriptif kualitatif. Sumber data primer dari penelitian ini adalah novel The Alchemist karya Paulo Coelho. Proses pengumpulan data adalah teknik mencatat. Penelitian ini juga termasuk penelitian kepustakaan. Berdasarkan temuan dan diskusi, peneliti menarik kesimpulan sebagai berikut. Pertama, ada enam elemen atau nilai-nilai yang mencirikan seseorang sebagai orang yang memiliki pandangan hidup yang optimis dan yang tercermin sebagai simbol yang digunakan dalam novel ini. Mereka adalah nilai-nilai harapan, iman, kekuatan, perjuangan, pemikiran positif, dan rasa hormat. Kedua, bahwa ada dua belas simbol yang digunakan dalam The Alchemist, simbol-simbol itu dibagi menjadi tiga kelompok yang terdiri dari empat simbol karakter, dua simbol peristiwa atau konsep dan enam simbol benda. Hasil penelitian menunjukkan bahwa kedua belas simbol dalam The Alchemist adalah bagaimana penulis membahas Optimistic melalui kisah pencarian diri penulis. Menurut seluruh temuan itu, simbol-simbol itu mengarahkan para pembaca untuk memahami pesan Paulo Coelho bahwa setiap orang dapat menemukan kebahagiaan mereka dalam diri mereka sendiri.
\end{abstract}

Kata kunci: Konsep optimistis kehidupan, Simbol, Self-quest.

\section{INTRODUCTION}

Literature is an interpretation of a man's life by using language as its medium. According to Robert, (1993: 1) literature is writing which expresses and communicate thoughts, feelings, and attitudes toward life. It has also happened in a novel as one of the genres of literature. The Alchemist novel describes how the main character has the characteristic of optimism towards life, such as hope, faith, power/courage, struggle, positive thinking, and respect, also these characteristics are reflected by the symbol of character, events or concept and things. By paralleling the characteristic optimistic view of life and the symbol found in the novel, we can make an interpretation with the author's biography.

The researcher uses some references from the previous study to show the similarities, comparison, and differences in the novel The Alchemist. In analysis with the same issue of the previous study are reviewed as a reference to support this study, here are some of the previous studies: the first two, researchers Puspa (2007) novel entitled "Santiago's Self-actualization in the Alchemist based on Maslow" and Utomo (2008) entitled "Motivation of a boy to pursue his dream as seen in Paulo Coelho's The Alchemist." Have the same related theory with Abraham Maslow's humanistic 
psychology, is to analyze the characterization of the characters in the novel.

The second, these four, researchers Farizi (2013) entitle "Santiago Strife for Success in Paulo Coelho's The alchemist novel (1992)", Indrajani (2010) entitled "The meaning of nature for Santiago in his effort to find the real Happiness in The Alchemist." and D. Nawang (2010) entitle "Listening to Heart, Pursuing dreams and world's reality, interpretation of symbols used in the Alchemist novel by Paulo Coelho." Hasanah, (2008) entitle "Decision Making in Paulo Coelho's The Alchemist." This researcher has the similarity concept using symbols, in the novel.

The third, these three researchers Chirstina (2009) entitled "Santiago Process of becoming an optimistic person in Paulo Coelho's The Alchemist," Wibowo (2007) entitled "The optimistic of Julia Stanford in Sydney Sheldon's Morning, Noon, and Night: An individual Psychological Approach", Susanti (2013) entitled "Optimism of Larry Crowne reflected in Tom Hank's Larry Crowne movie (2011): An individual Psychological Approach", These researcher has the similarity value using Optimistic, in the novel.

Using those previous studies from other researchers can help the writer in analyzing the data in this paper, the writer focuses on the optimistic view of life in the novel. This research is conducted to analyze the uses of symbols in reflected with the optimistic view of life through the attitudes of the character, towards optimistic view of life, by analyzing those features, the writer can draw a similarity about how Paulo Coelho stance on an optimistic view of life-based on his biography, also how the story can affect the readers especially teenagers junior-senior high school, college students and adult to view life in Optimistic way.

\section{THEORETICAL FOUNDATION}

The research uses two approaches the first is an Optimistic view of life and a Biographical Approach to analyze the symbols in The Alchemist.

Related to Optimistic of life some scholars have defined optimistic term into some definitions. According to Oxford Advanced Learner's Dictionary of Current English, the meaning of Optimistic is expecting the best; a confident Optimist is a person who is always hopeful and looks upon the bright side of things, who believes that all things happen for the best. Keller (2010:p.1113) says that Optimism is the faith that leads to achievement; nothing can be done without hope, the harmony between man's spirit and the spiritual faith to God pronouncing his good works. According to Peale (2014:p.921) faith can increase energy, it achieves the most tremendous things and overcomes any obstacle by faith power. While Seligman (2006: p.15) says Optimism is not a rediscovery of the "power of positive thinking", thinking positively and expecting positive results, having self-confident and strong effort to view every event and bad situation which is happening in real life with positive thought because of great expectation which never stops the mind and feeling. Based on the above statement, the writer concludes that the characteristic of the Optimists is someone who has the following characteristics; (a) having great hope, (b) having strong faith, (c) building power, (d) challenging to struggle, (e) heightening positive thinking, (f) heightening respect.

Biographical critics see works as the reflection of an author's life and times (or of the characters' life and times). This approach deems it is necessary to know about the author and the political, economic, and sociological contexts of these times in order to truly understand the works. It examines the literary work in relation to the author's life. Relating the work with the author is necessary to truly understand the work, including the symbols and the allusions in it. In addition, the political, sociological, economic or cultural contexts of the time the work was being made are also important to add more essential information to analyze the work. According to Wellek, there are some intrinsic elements of the literary works such as structure, style, theme, characters, plot, symbols, etc. This paper only focuses on symbols in the novel, as he states, "If it persistently recurs, both as presentation and representation, it becomes a symbol." 
(Wellek, 189). He also states additional important things, that is:

"The most widespread and flourishing method of studying literature concern themselves with its setting, its environment, its external causes. These extrinsic methods are not limited to a study of the past but are equally applicable to present-day literature" (Wellek, 73).

According to website http://literarydevices.com/content/symbol, a symbol is a literary device that contains several layers of meaning, often concealed at first sight, and is representative of several other aspects, concepts or traits than those that are visible in the literal translation alone. The symbol is using and object or action that means something more than its literal meaning. While the symbolism is the use of symbols to signify ideas and qualities by giving them symbolic meanings that are different from their literal sense. Symbolism can take different forms. Generally, it is an object representing another to give it an entirely different meaning that is much deeper and more significant. Symbols do shift their meaning depending on the context they are used in.

In analyzing this novel, the writer uses two aspects consisting of the analyze biography of the author with the meaning of Symbols in the novel and with that can reveal the message of an Optimistic view of life in the novel The Alchemist.

\section{RESEARCH METHOD}

The writer uses descriptive qualitative research to analyze the novel. Descriptive means that in this research the researcher describes the data from the words and the utterances used in the novel The Alchemist. Then, it is called as qualitative, because the data in this study does not deal with numbers. Therefore, the writer chooses a descriptive qualitative method as the appropriate method since the data are explained descriptively. The first step is determining the object study. The second is determining the source data. The third is determining the method of data collection. The forth is determining the techniques of data analysis. The main data is The Alchemist novel. And the secondary data source is taken from another source related to the study such as the internet, books of literary and psychoanalytic theory to analyze. In order to collect the data, the writer took some steps. The steps of the collecting data are as follows : (a) Reading the novel (b) Exploring and develops the data from source of data (c) Going to the library to read some books as reference (d) Reading some ebooks and other references related to the study (e) Analyzing the reference and make the finding that the alchemist is full of Optimistic view of life is reflected through the symbols in the Alchemist novel by Paulo Coelho. The researcher uses symbols and describing the values of the optimistic view of life.

\section{RESEARCH FINDING AND DISCUSSION}

In conducting the research, the researcher draws some results as follows. Such as the definition of Characteristic of optimism of life, symbols use to reflect the characteristic of life, and the symbols used in addressing the optimistic view of life.

\subsection{Characteristic of Optimism of life and The uses of Symbols in Addressing Optimistic view of life by Paulo Coelho}

Hope: Among the other elements of Optimism 'hope' is the top optimism element. Hope and faith are the essences of optimism since optimism means the faith to realize hope. The Optimist considers hope as men's future. Reaching hope is the optimist's basic purpose of life. When a man lives with no hope, their life will be in a mess. Hope will lead the man into a meaningful life. For them hope is motivation and assets of their future. Hope in this novel can be shown by the following symbol of the character Santiago express the value of hope.

Faith: Faith is a stronger belief towards the ability to realize hope. The ones who have an optimistic life have a strong faith which will lead them to their success. They put it in their minds and heart. Faith can generate good 
energy and strength which is essential elements to realize their hope or dream. Optimism is identical to faith and achievement in which they are equally balanced, it means the strong faith someone has the easier he or she get success or achievement. Faith and confidence can control fear and doubt in facing danger, pain or misfortune. Faith in this novel can be shown by the following symbol of the character Fatima express the value of hope.

Power: In real life power or strength influences the success of someone in reaching their goal. Men move, act, and work to proceed with life. Human power is not only their physical and mentally but also spiritually and social power. The one who is strong physically will do the works which needs great power, the one who works in a dangerous job needs strong mentality, ones who have strength in social will have great influence in society. Men rise their strength or power in several ways. Food and exercise can generate physical strength, sense of faith generates energy and spirit. The sense of socializing will raise relationship. The condition of being healthy physically and mentally will make a man happy and this can cause generating power through the energy released by a sense of happiness. That's why the optimists always have great power. The optimists have the ability to motivate themselves and also motivate other people, they have the power to eliminate negative thinking. The optimists consider that bad luck is part of life and consider every of it from positive views. They think that everybody has a bad side and it can be eliminated by developing their ability by filling the mind with creative and good thought. The following symbol illustrates optimism value which is described above. Power in this novel can be shown by the following symbol of the character the alchemist express value of power.

Struggle: Life provides man with two things that give each opposition, such as life and death, pride and lose, gift and problem, and etc. To show their existence, man must struggle to solve everything from obstacles that are blocking them from reaching what they want to achieve. In real life, every man faces many disturbances, such as weather, fear, warfare, fate and free will, wisdom and knowledge, love, dreams, hope and plans, and many other problems are part of life. These must not be hindered but must be faced and solved. Men will compete with others for pride, status, and satisfaction. Every victory comes after a struggle. And the great victory must have struggled greatly. The one's experiences, mental power, physical strength, will help man to fight against the disturbance. For the optimist's struggle always brings pain sometimes physically and sometimes mentally or both of them and each struggle and each struggle needs sacrifice and also spends power and energy. Perseverance and endurance are needed along with struggling. The following symbol expresses this kind of value. Struggle in this novel can be shown by the following symbol of events when Santiago comes back to where he started to express the value of struggle.

Positive thinking: Thinking positively will give men a good atmosphere both in the heart and brain so men can think everything in clear thought thus it drives men to do the truth. It also prevents men from boastful which can danger themselves. The power of positive thinking also meant the power of driving negative thinking away from the mind. The optimists consider that bad luck is part of life and consider every of it from positive views. The optimists possess positive thinking to whatever they experience or face. They consider that everybody has a bad side and it can be eliminated with the power of positive thinking by developing their ability in filling the mind with creativity and good thought. Positive thinking in this novel can be shown by the following symbol of thing which is the Urim - Thummim stones express the value of positive thinking.

Respect: The optimists are the persons who respect others, they consider that appreciation generates a positive atmosphere among them. The one who has optimistic about life is not mean to praise the other one. The optimists spread love and a sense of warmth to people around them. They see beautifulness in every aspect of life. So the expression of 'thank you' is always expressed in words or in the heart. The optimists have strong affection, warmth, 
love, and tender feeling to others. No matter they are human or not, but they know who is fair to appreciate. The following symbol provides a value of respect as one of the characteristics of optimism element. Respect in this novel can be shown by the following symbol of thing which is the sheep express value of respect.

\section{CONCLUSION}

The conclusion is that The Alchemist novel contains the values of an optimistic view of life as illustrated in the theme. The values are reflected in the symbols used in the novel. This novel provides positive human values which is useful for the readers from junior-senior high school, college student to adults. Through these values reflected in its symbol, this novel can generate people's motivation to behave well not only to other people but also to the environment besides that it can motivate themselves in order that they can be a success in all fields in their life. Thus this novel has great values which are reflected by some elements of this fiction such as theme and symbol as one aspect of language. It can be stated that Coelho's novel The Alchemist has a good style where the readers can get great benefit especially getting a life learning after reading it. Coelho has so many great experiences of life as a traveler he has ever experienced a hard life. That the temptation sometimes makes us give up on the situation, but by giving up it sometimes even destroys ourselves, because it is kept away from our dreams. Dreams or life goals must be pursued and fought for. It's best and wise we don't give up on the situation, because the more trials, problems and things that block the process of achieving our dreams the more it makes us stronger, wiser and more master of understanding and knowledge, which in the end we unexpectedly, we will end up find our true happiness. By implementing the characteristic of Optimistic view of life, because we want to strive to achieve our dreams without giving up, when stopped we only stop temporarily to adjust the situation, or when being confronted by a problem, it will only make us a better person, and more surprising for ourselves we are precisely that actually our happiness and dreams are around us and are in our hearts.

Finally related to the problem found in this novel is that there are some people who are not able to achieve their goals or desires. To the contribution of the study to pedagogical implication, education aspect to the Teacher and the students of junior-senior high school and also for the college - student in achieving their dream, he/she has to have a strong effort and struggle to make the dream comes true. We can take the example of the character of Santiago the person who has an optimistic view of life and positive thinking, and not only as a hard worker but also never give up to overcome the challenges in his journey with optimistic views of life. Furthermore, the teachers are expected to be able to build students' good character by introducing and practicing some moral values, educational, and social values that are very well described in The Alchemist novel. In the social life, we can take the example of the character Santiago, where he welcomes every kind of people such as the Gypsies woman, the old man from Salem (King Melchizedek), The Crystal merchant, An Englishman, Fatima, and the Alchemist. The values can be adopted in the ideology of Pancasila Bhineka Tunggal Ika, where people should never make the differences of others, and people can take so many experiences from the person they have known especially the human being, positive values and human value which is useful for an optimistic view of life.

\section{BIBLIOGRAPHY}

Abrams, M.H. A Glossary of Literature Terms. New York: Cornel University. 1981

Baldick, Chris, 2001. The Concise Oxford Dictionary of Literature Terms. Oxford: Oxford University Press.

Biography of Paulo Coelho. Published by: UK Free Documentation December 26, 2008 (http://www.ukfreedocumentation.co.uk/coelho/ paulo/bio.shtml-707k) 
Coelho, Paulo. The Alchemist. New York: HarperCollins Publisher Inc. 1988

Culler Jonathan, 1994. Structuralist Poetic Structuralism, Linguistic and the study of literature. London: Routledge.

D. Nawang Wulan E. P. S. 2010. "Listening to Heart, Pursuing Dreams and World's Reality, Interpretation of symbol used in the Alchemist novel by Paulo Coelho" Diponegoro University Semarang.

Fajriani. The Life of Paulo Coelho as Reflected in The Alchemist: An Expressive Approach. Undergraduate Thesis. Sulawesi: West Sulawesi University. 2003

Farizi, Ilmam, Dani. 2013. "Santiago' Strife for Success in Paulo Coelho's The Alchemist novel (1992): An Individual Psychological Approach". Muhammadiyah University Surakarta.

Frederik, Juliana Tirajohn, 1988. ENGLISH POETRY An Introduction to Indonesian Students, Jakarta: Departemen Pendidikan dan Kebudayaan Direktorat Jenderal Pendidikan Tinggi Proyek Pengembangan lembaga Pendidikan Tenaga Kependidikan.

Gradesaver LLC, Biography of Paulo Coelho. December 26, 2008.

(http://www.gradesaver.com/the alchemistcoelho/Studyguide/essayquestions)

Holman, H. (1960). A Handbook To Literature (4 ed.). Indiana: Bobbs-Merill Educational Publishing.

Indrajati. T, Nani, 2010. The Meaning of Nature for Santiago in his Effort to Find the Real Happiness in The Alchemist. Petra Christian University Surabaya.

Kenney, W. (1966). How To Analyze Fiction. New York: Monarch Press.

Koesnosoebroto, Sunaryono Basuki, 1988. The Anatomy of Prose Fiction. Jakarta: Departement Pendidikan Dan Kebudayaan Direktorat Jenderal Pendididkan Tinggi Proyek Pengembangan Lembaga Pendidikan Tenaga Kependidikan.

Kremenik, Michael J. The Search for the Hero's Soul in The Alchemist. Kawasaki Journal of Medical Welfare, Vol. 2, No. 2, 1996, pp. 123-131.

Official Site Paulo Coelho, Faq The Books. Retrieved February 24, 2009 (http://www.paulocoelho.com.br/engl/faq. shtml)

Leech, Geoffrey N and Michael H Short, 1981, Style in fiction, A linguistic introduction to English fictional prose.
Edinburgh Gate Harlow, Essex CM202JE, England: Pearson Education Limited.

Ortolono, Glauco. An Interview with Paulo Coelho: The Coming of Age of a Brazilian Phenomenon. Journal of World Literature Today, Vol. 77, No. 1 (Apr. - Jun., 2003), pp. 57-59 . Published by: Board of Regents of the University of Oklahoma Stable (URL: http://www.jstor.org/stable/40157785).

Peck, John, and Martin Coyle, 1986. Literary Terms and Criticism. London: Macmillan Education Ltd.

Pickering, James H and Jeffery D Hopper, 1981. Concise Companion to literature.

New York: Macmillan Publishing Co, Inc. Puspa, Sari, 2007. Santiago's Self Actualization in the Alchemist based on Maslow Humanistic Psychology. Sanata Dharma University Yogyakarta.

Rabiega, Joseph and Brooke. J, Cannon 2013. "The Relationship of Optimism with Psychological and Physical Well being. Marywood University Pennsylvania.

Rees, R. J. 1973. English Literature: An Introduction for foreign Readers. Basinstoke and London: Macmillan Education Ltd.

Satoto, Sudiro, 1995. STILISTIKA. Surakarta: STSI.

Sebeok, Thomas, 1994. An Introduction to Semiotics. 25 Floral Street, Convent Garden, London, WC2E9DS, United Kingdom: Printer Publishers.

Seligman, Martin E.P, 2006. Learned Optimism how to change your mind and your life. New York: VINTAGE BOOKS.

A Division of Random House, Inc.

Sobur, Alex, 2006. Semiotika

Komunikasi, Bandung: Penerbit PT Remaja Rasdakarya.

Utomo, Permadi, Eko, 2008. "Motivation of a boy to pursue his dream as seen in Paulo Coelho's The Alchemist". Soegijapranata Catholic University Semarang.

Walgito, Bimo, 2010. Pengantar Psikologi Umum, Yogyakarta: Penerbit Andi.

Wibowo, Raindri 2007. "The optimism of Julia Stanford in Sydney Sheldon's Morning, Noon and Night: An individual Psychological Approach". Muhammadiyah University 
Surakarta.

Wellek, Rene and Austen, Warren. Theory of Literature. New York: Harcourt Brace and Word, Inc. 1956.

Wellek, Rene and Austin Warren, 1949. Theory of literature. New York: Harcourt Brace and Company.
VIRTUAL REFERENCE

http://www.bbc.co.uk/bitesize/higher/English/ close-reading/imagery/revision.

http://users.humboldt.edu/tduckart/symbolism .htm.

http://grammar.about.com/od/rs/g/stylisticsterm.htm. 